\title{
Effect of different concentrations of potassium on pig embryos developing in vitro
}

\author{
N. H. Kim ${ }^{*}$ and A. R. Menino, $\mathrm{Jr}^{\dagger}$ \\ Department of Animal Sciences, Oregon State University, Corvallis, OR 97331-6702, USA
}

\begin{abstract}
The effects of varying the potassium concentration in Whitten's medium on the development of pig embryos in vitro was investigated. Osmolality was maintained by adjusting the $\mathrm{NaCl}$ concentration. In Expt I, 209 one-cell to early blastocyst stage embryos were individually cultured in $50 \mu \mathrm{l}$ microdrops of glucose-free Whitten's medium containing $0.4 \%$ $(\mathrm{w} / \mathrm{v}) \mathrm{BSA}$ and $1.5,3.0,6.0$ or $12.0 \mathrm{mmol}$ potassium $\mathrm{l}^{-1}$. The percentages of embryos undergoing blastocoel formation and expansion for each cell stage evaluated did not differ $(P>0.10)$ among the various concentrations of potassium. However, more four-cell embryos commenced hatching in $3.0 \mathrm{mmol}$ potassium $1^{-1}(53 \%)$ than in $1.5 \mathrm{mmol}$ potassium $\mathrm{l}^{-1}(16 \%)(P<0.05)$ and $12.0 \mathrm{mmol}$ potassium $\mathrm{l}^{-1}(24 \%)(P<0.10)$. The time required for embryos to develop blastocoels, expand and initiate hatching was not affected $(P>0.10)$ by the concentration of potassium in the medium. However, blastocoel formation by one- to two-cell embryos was delayed $(P<0.05)$ in medium with $1.5 \mathrm{mmol}$ potassium $1^{-1}$. In Expt 2, 89 four-cell embryos were cultured in medium containing 6.0 or $24.0 \mathrm{mmol}$ potassium $1^{-1}$. No differences $(P>0.10)$ were observed in the percentages of embryos undergoing blastocoel formation, expansion and hatching or in the time required to develop to these stages. The number of cells in embryos recovered at $96 \mathrm{~h}$ was greater $(P<0.05)$ in medium containing 6.0 compared with $24.0 \mathrm{mmol}$ potassium $\mathrm{l}^{-1}(32.9 \pm 1.7$ versus $26.9 \pm 2.1$, respectively). These results demonstrate that pig embryos are tolerant to a wide range of potassium concentrations when the osmolality of the medium is maintained by adjusting the $\mathrm{NaCl}$ concentration. These results also suggest that limitations in development due to culture conditions are not due to inappropriate concentrations of this ion.
\end{abstract}

\section{Introduction}

Determination of optimal concentrations of medium constituents that will support prolonged development of early embryos such that high percentages reach the blastocyst stage is essential for successful embryo production in vitro. Previous studies with mouse embryos have shown that development is sensitive to the concentration of potassium in the culture medium. Wiley (1984) and Wiley et al. (1986) reported that reduced potassium ( 0.6 and $1.4 \mathrm{mmol} \mathrm{l}^{-1}$ ) accelerated development of two- to four-cell stage embryos and morulae into blastocysts compared with medium with $6 \mathrm{mmol}$ potassium $1^{-1}$ (Biggers et al., 1971). However, Roblero and Riffo (1986) reported that a high potassium concentration $\left(25 \mathrm{mmol} \mathrm{l^{-1 }}\right)$, similar to that found in the mouse oviduct, increased the number of cells of morulae and blastocysts developing from two-cell embryos compared with embryos cultured in medium with $4.7 \mathrm{mmol} \mathrm{I}^{-1}$. Studies in several species have demonstrated higher potassium concentrations in reproductive tract fluids compared with the bloodstream (Iritani et al., 1974;

*Present address: Animal Resources Research Center, Kon-Kuk University, 93-1 Mojin-dong, Seoul 133-701, Korea.

${ }^{\dagger}$ Reprint requests.

Received 5 February 1997
Roblero et al., 1976; Borland et al., 1980). Potassium concentrations in the oviductal and uterine fluids of pigs are 12.5 and $16.0 \mathrm{mmol} l^{-1}$, respectively, and are considerably higher than the $4-6 \mathrm{mmol} \mathrm{l}^{-1}$ traditionally found in culture media (Iritani et al., 1974). This difference in potassium may contribute to the reduced development observed in embryos cultured from the early cleavage stages. Therefore, the purpose of this study was to investigate the effects of varying the potassium concentration on development of pig embryos in vitro.

\section{Materials and Methods}

Two experiments were conducted to evaluate the effects of potassium on numbers of embryonic cells and development to the blastocyst stage. Expt 1 was designed to evaluate the development of pig embryos collected at various cell stages to the blastocyst and hatched blastocyst stages in medium containing $1.5,3.0,6.0$ or $12.0 \mathrm{mmol}$ potassium $\mathrm{l}^{-1}$. Expt 2 was designed to assess development to the blastocyst stages after $96 \mathrm{~h}$ and $168 \mathrm{~h}$ of culture and the number of embryonic cells at $96 \mathrm{~h}$ for pig embryos at the four-cell stage cultured in medium

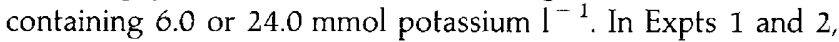
cyclic Yorkshire and Hampshire cross gilts and sows were 
Table 1. Development in vitro of pig embryos in Whitten's medium containing 1.5, 3.0, 6.0 or $12.0 \mathrm{mmol}$ potassium $1^{-1}$

\begin{tabular}{|c|c|c|c|c|c|c|}
\hline \multirow[b]{2}{*}{$\begin{array}{l}\text { Initial } \\
\text { cell stage }\end{array}$} & \multirow{2}{*}{$\begin{array}{c}\text { Potassium } \\
\text { concentration } \\
\left(\mathrm{mmol} 1^{-1}\right)\end{array}$} & \multirow{2}{*}{$\begin{array}{l}\text { Number of } \\
\text { embryos } \\
\text { cultured }\end{array}$} & \multicolumn{4}{|c|}{ Number (percentage) of embryos developing to the: } \\
\hline & & & Blastocyst & $\begin{array}{l}\text { Expanded } \\
\text { blastocyst }\end{array}$ & $\begin{array}{l}\text { Hatching } \\
\text { blastocyst }\end{array}$ & $\begin{array}{l}\text { Hatched } \\
\text { blastocyst }\end{array}$ \\
\hline \multirow{4}{*}{$\begin{array}{l}\text { One- and } \\
\text { two-cell }\end{array}$} & 1.5 & 10 & $(80)$ & $2(20)$ & $1(10)$ & - \\
\hline & 3.0 & 10 & $8(80)$ & $6(60)$ & $3(30)$ & - \\
\hline & 6.0 & 10 & $7 \quad(70)$ & $4(40)$ & $3(30)$ & - \\
\hline & 12.0 & 12 & $11 \quad(92)$ & $4(33)$ & $1 \quad(8)$ & - \\
\hline \multirow[t]{4}{*}{ Four-cell } & 1.5 & 19 & $19(100)$ & $10(53)$ & $3(16)$ & $1(5)$ \\
\hline & 3.0 & 17 & $15 \quad(88)$ & $11(65)$ & $9(53)^{a . b}$ & $0(0)$ \\
\hline & 6.0 & 19 & $16(84)$ & $11(58)$ & $6(32)$ & $0(0)$ \\
\hline & 12.0 & 17 & $17(100)$ & $10(59)$ & $4(24)$ & $0(0)$ \\
\hline \multirow{4}{*}{$\begin{array}{l}\text { Morula } \\
\text { and early } \\
\text { blastocyst }\end{array}$} & 1.5 & 25 & $25(100)$ & $23(92)$ & $14(56)$ & $2(8)$ \\
\hline & 3.0 & 24 & $22 \quad(92)$ & $19(79)$ & $13(54)$ & $2(8)$ \\
\hline & 6.0 & 22 & 21 & $21(95)$ & $13(59)$ & $2(9)$ \\
\hline & 12.0 & 24 & $22 \quad(92)$ & $22(92)$ & $13(54)$ & $1(4)$ \\
\hline
\end{tabular}

${ }^{a}$ Significantly different from development of four-cell embryos in medium with 1.5 mmol potassium $1^{-1}(P<0.05)$.

${ }^{b}$ Significantly different from development of four-cell embryos in medium with 12.0 mmol potassium $l^{-1}(P<0.10)$.

checked daily for oestrus and hand-mated with boars of proven fertility. In addition, in Expt 1, eight prepubertal gilts were synchronized and superovulated (Baker and Coggins, 1968) with i.m. injections of 1500 i.u. pregnant mares' serum gonadotrophin (Calbiochem-Behring Corp., San Diego, CA) followed 48 h later by 500 i.u. hCG (Sigma Chemical Co., St Louis, MO) and then artificially inseminated with commercial semen $24 \mathrm{~h}$ and $48 \mathrm{~h}$ after hCG (Baker and Coggins, 1968). Prepubertal gilts displaying oestrus after hormone treatment were also hand-mated. Reproductive tracts were recovered at slaughter and oviducts and uteri were flushed with Whitten's medium (Whitten and Biggers, 1968) without glucose (Youngs et al., 1993) and BSA. Flushings were collected into embryological dishes and observed at $\times 10$ magnification with a dissecting microscope for the presence of the embryos. Embryos were transferred to microdrops of glucose-free Whitten's medium with $4 \mathrm{mg} \mathrm{BSA} \mathrm{ml}^{-1}$ (Sigma Chemical Co.) and their morphology was evaluated. Embryos with normal morphology ranging in development from one-cell to early blastocyst stages were randomly allocated to Whitten's medium contain-

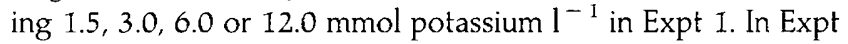
2 , four-cell embryos were randomly allocated to Whitten's medium containing 6.0 or $24.0 \mathrm{mmol}$ potassium $\mathrm{l}^{-1}$. Potassium concentration was varied by manipulating the amount of $\mathrm{KCl}$ added to the medium. Osmolality and chloride concentration were maintained by adjusting the $\mathrm{NaCl}$ concentration. Embryos were cultured individually in $50 \mu \mathrm{I}$ microdrops of Whitten's medium under paraffin oil in a humidified atmosphere of $5 \%$ $\mathrm{CO}_{2}$ in air at $39^{\circ} \mathrm{C}$. Embryos were evaluated for cell stage and morphology at $\times 100-200$ magnification with an invertedstage phase-contrast microscope at intervals of $24 \mathrm{~h}$ until the end of culture. Embryos were cultured for $168 \mathrm{~h}$ in Expt 1 , and for 96 and $168 \mathrm{~h}$ in Expt 2. Embryos cultured for $96 \mathrm{~h}$ in Expt 2 were fixed and stained with haematoxylin and eosin for assessment of numbers of cells (McGaughey and Chang, 1969).

\section{Statistical analyses}

Differences in the percentages of embryos developing to a particular cell stage due to treatment were determined by Chi-square procedures for contingency tables (Steel and Torrie, 1980). Differences in the times required for embryos to develop to the blastocyst stages due to concentration of potassium were determined using one-way ANOVA and Fisher's least significant differences procedures for Expt $I$ and the unpaired $t$ test for Expt 2. Numbers of embryonic cells in Expt 2 were also analysed using the unpaired $t$ test. All analyses were performed using the NCSS statistical software program (Number Cruncher Statistical System, Version 4.1, 1984, J. L. Hintze, Kaysville, UT).

\section{Results}

A total of 209 morphologically normal one-cell to early blastocyst stage embryos were recovered from 18 females for Expt 1. Sufficient numbers of embryos were collected from each female to allow allocation of embryos to all four treatments. Incidences of blastocyst formation and blastocoel expansion did not differ $(P>0.10)$ as a result of potassium concentration for any of the cell stages cultured (Table 1). Potassium concentration did not significantly $(P>0.10)$ affect the number of embryos that began hatching when embryos were cultured from the one- and two-cell or morula and early blastocyst stages. However, more four-cell embryos began hatching when cultured in Whitten's medium with $3.0 \mathrm{mmol}$ potassium $\mathrm{I}^{-1}$ than in media containing $1.5(P<0.05)$ or $12.0 \mathrm{mmol}(P<0.10)$ potassium $1^{-1}$. One- and two-cell embryos and morulae and early blastocysts were originally analysed separately but because no significant differences in development were observed, the data were combined in Table 1 for more concise presentation of the results. 
Table 2. Times (h) from initiation of culture to blastocyst formation, expansion and onset of hatching for pig embryos developing in Whitten's medium containing $1.5,3.0,6.0$ or $12.0 \mathrm{mmol}$ potassium $\mathrm{l}^{-1}$

Time to:

\begin{tabular}{|c|c|c|c|c|c|c|c|c|}
\hline \multirow{3}{*}{$\begin{array}{l}\text { Initial } \\
\text { cell stage }\end{array}$} & \multirow{3}{*}{$\begin{array}{l}\text { Potassium } \\
\text { concentration } \\
(\mathrm{mmol} \mathrm{l}\end{array}$} & \multirow{3}{*}{$\begin{array}{l}\text { Number of } \\
\text { embryos } \\
\text { cultured }\end{array}$} & \multirow{2}{*}{\multicolumn{2}{|c|}{$\begin{array}{l}\text { Blastocoel } \\
\text { formation }\end{array}$}} & & & & \\
\hline & & & & & \multicolumn{2}{|c|}{$\begin{array}{l}\text { Blastocoel } \\
\text { expansion }\end{array}$} & \multicolumn{2}{|c|}{$\begin{array}{l}\text { Onset of } \\
\text { hatching }\end{array}$} \\
\hline & & & $n$ & Mean $\pm S E$ & $n$ & Mean $\pm \mathrm{SE}$ & $n$ & Mean $\pm \mathrm{SE}$ \\
\hline \multirow{4}{*}{$\begin{array}{l}\text { One- and } \\
\text { two-cell }\end{array}$} & 1.5 & 10 & 8 & $120 \pm 5^{\mathrm{a}}$ & 2 & $168 \pm 15$ & 1 & 168 \\
\hline & 3.0 & 10 & 8 & $105 \pm 5^{b}$ & 6 & $140 \pm 9$ & 3 & $144 \pm 14$ \\
\hline & 6.0 & 10 & 7 & $96 \pm 5^{b}$ & 4 & $132 \pm 11$ & 3 & $144 \pm 14$ \\
\hline & 12.0 & 12 & 11 & $100 \pm 4^{\mathrm{b}}$ & 4 & $138 \pm 11$ & 1 & 144 \\
\hline \multirow[t]{4}{*}{ Four-cell } & 1.5 & 19 & 19 & $72 \pm 4$ & 10 & $106 \pm 7$ & 3 & $128 \pm 13$ \\
\hline & 3.0 & 17 & 15 & $69 \pm 4$ & II & $96 \pm 6$ & 9 & $109 \pm 7$ \\
\hline & 6.0 & 19 & 16 & $64 \pm 4$ & 11 & $98 \pm 6$ & 6 & $112 \pm 9$ \\
\hline & 12.0 & 17 & 17 & $65 \pm 4$ & 10 & $89 \pm 7$ & 4 & $102 \pm 11$ \\
\hline \multirow[t]{4}{*}{ Morula } & 1.5 & 13 & 13 & $28 \pm 2$ & 12 & $42 \pm 4$ & 8 & $60 \pm 6$ \\
\hline & 3.0 & 12 & 10 & $26 \pm 2$ & 7 & $34 \pm 5$ & 6 & $56 \pm 7$ \\
\hline & 6.0 & 10 & 9 & $24 \pm 2$ & 9 & $45 \pm 4$ & 6 & $56 \pm 7$ \\
\hline & 12.0 & 13 & 11 & $26 \pm 2$ & 11 & $41 \pm 4$ & 4 & $60 \pm 9$ \\
\hline \multirow{4}{*}{$\begin{array}{l}\text { Early } \\
\text { blastocyst }\end{array}$} & 1.5 & 12 & 12 & - & 11 & 24 & 6 & $36 \pm 6$ \\
\hline & 3.0 & 12 & 12 & - & 12 & 24 & 7 & $34 \pm 6$ \\
\hline & 6.0 & 12 & 12 & - & 12 & 24 & 7 & $34 \pm 6$ \\
\hline & 12.0 & 11 & 11 & - & 11 & 24 & 9 & $32 \pm 5$ \\
\hline
\end{tabular}

${ }^{\text {a.b }}$ Means within a column for the same initial cell stage lacking a common superscript are significantly different $(P<0.05)$.

Times required for embryos in Expt 1 to develop blastocoels, undergo blastocoelic expansion and begin hatching are reported (Table 2). One- and two-cell embryos cultured in Whitten's medium containing $1.5 \mathrm{mmol}$ potassium $\mathrm{l}^{-1}$ developed more slowly $(P<0.05)$ to the blastocyst stage than did embryos cultured in Whitten's medium containing 3.0, 6.0 or $12.0 \mathrm{mmol}$ potassium $\mathrm{I}^{-1}$. Although this delay persisted up to blastocoel expansion and onset of hatching, significant differences were not observed. Differences in developmental times among the four concentrations of potassium were not observed for four-cell embryos, morulae or early blastocysts.

Eighty-nine embryos at the four-cell stage and of normal morphology were recovered from nine females and cultured in Expt 2. No differences $(P>0.10)$ in development of four-cell embryos to a particular cell stage were observed in Whitten's medium containing 6.0 or $24.0 \mathrm{mmol}$ potassium $\mathrm{I}^{-1}$ at $96 \mathrm{~h}$ of culture (Table 3). However, embryos developing in Whitten's medium containing $24.0 \mathrm{mmol}$ potassium $\mathrm{l}^{-1}$ had fewer $(P<0.05)$ cells at $96 \mathrm{~h}$ of culture than did embryos in Whitten's medium containing $6.0 \mathrm{mmol}$ potassium $\mathrm{l}^{-1}$ (Table 3). When four-cell embryos were cultured for $168 \mathrm{~h}$, no differences $(P>0.10)$ in development to the blastocyst, expanded blastocyst and hatching stages were observed (Table 4). Although development tended to be faster in Whitten's medium containing $24.0 \mathrm{mmol}$ potassium $\mathrm{l}^{-1}$, no significant differences were observed (Table 4).

\section{Discussion}

Although culture of cleavage stage pig embryos to the blastocyst stage has been accomplished in simple medium with
Table 3. Development of pig embryos from the four-cell stage after $96 \mathrm{~h}$ of culture in Whitten's medium containing 6.0 or $24.0 \mathrm{mmol}_{\text {potassium } ~^{-1}}$

\begin{tabular}{lcc}
\hline & \multicolumn{2}{c}{$\begin{array}{c}\text { Potassium concentration } \\
\text { (mmol l- }\end{array}$} \\
\cline { 2 - 3 } Observation & 6.0 & 24.0 \\
\hline Number of embryos cultured & 42 & 47 \\
Percentage of embryos developing to: & & \\
$\quad$ Blastocyst & $83(35)^{\mathrm{a}}$ & $77(36)$ \\
Expanded blastocyst & $40(17)$ & $34(16)$ \\
Hatching blastocyst & $26(11)$ & $15(7)$ \\
$\quad$ Hatched blastocyst & $0(0)$ & $0(0)$ \\
Number of cells & $32.9 \pm 1.7^{\mathrm{c}}$ & $26.9 \pm 2.1$ \\
& $(19)$ & $(23)$
\end{tabular}

\footnotetext{
${ }^{3}$ Values in parentheses are the numbers of embryos.

'Twenty-four embryos were fixed and stained for each concentration of potassium. Five embryos and one embryo cultured in medium containing 6.0 or $24.0 \mathrm{mmol}$ potassium $\mathrm{I}^{-1}$, respectively, either were lost or did not yield satisfactory preparations during processing.

'Significantly different from $24.0 \mathrm{mmol}$ potassium $\mathrm{l}^{-1}(P<0.05)$.
}

BSA or serum, development of a high percentage of embryos from the early cleavage stages to hatching in such medium is limited (Reed et al., 1992; Petters and Wells, 1993). The development of pig embryos has been improved with more complex systems using mouse oviduct organ culture (Krisher $e t$ al., 1989; Reed et al., 1992), co-culture with oviductal epithelial 
Table 4. Development of pig embryos from the four-cell stage after $168 \mathrm{~h}$ of culture in Whitten's medium containing 6.0 or $24.0 \mathrm{mmol}^{\text {potassium } \mathrm{l}^{-1}}$

Potassium concentration $\left(\mathrm{mmol} \mathrm{l}^{-1}\right)$

\begin{tabular}{lcr}
\cline { 2 - 3 } Observation & 6.0 & 24.0 \\
\hline Number of embryos cultured & 18 & 23 \\
Percentage of embryos developing to: & & \\
$\quad$ Blastocyst & $94(17)^{\mathrm{a}}$ & $87(20)$ \\
$\quad$ Expanded blastocyst & $72(13)$ & $52(12)$ \\
Hatching blastocyst & $56(10)$ & $39(9)$ \\
Hatched blastocyst & $0(0)$ & $4(1)$ \\
Time ${ }^{b}$ (h) to: & & \\
Blastocoel formation & $75 \pm 6(17)$ & $65 \pm 4(20)$ \\
Blastocoel expansion & $103 \pm 6(13)$ & $92 \pm 5(12)$ \\
Onset of hatching & $115 \pm 8(10)$ & $101 \pm 7(9)$ \\
\hline
\end{tabular}

${ }^{a} V$ alues in parentheses are the numbers of embryos.

bValues are means \pm SE.

cells (White et al., 1989) and with medium containing oviductal fluid (Archibong et al., 1989). Pollard and coworkers (1995) designed an optimal culture system that supported the development of a large proportion of pig zygotes through blastulation and hatching. In this system, pig zygotes were cultured first in simple medium (CZB; Chatot et al., 1989) up to the morula stage and then transferred to modified Eagles' minimum essential medium containing glucose, non-essential amino acids, vitamins, insulin and serum (Pig-MEM; Pollard et al., 1995). Difficulties encountered in designing a single culture medium that can support development of zygotes to hatching may be due to ionic imbalances or to the absence of beneficial macromolecular components such as growth factors.

The importance of the physiologically high potassium concentration in the oviductal and uterine microenvironments of the preimplantation embryo is not understood. Previous work has suggested that the high potassium concentration influences sperm motility and sperm-egg fusion (Boldt et al., 1991). Roblero and Riffo (1986) observed a dose-related increase in the rate of cleavage of mouse embryos with 4.7, 10 and $25 \mathrm{mmol}$ potassium $^{-1}$. Their results suggest that potassium concentrations similar to those found in the mouse genital tract improved development in vitro. However, conflicting results with mouse embryos have been observed (Wiley, 1984; Wiley et al., 1986). Cavitation was accelerated when potassium was decreased from 60 to $0.5 \mathrm{mmol} \mathrm{l}^{-1}$ and was delayed when potassium was increased from 6 to $25 \mathrm{mmol} \mathrm{l}^{-1}$ (Wiley, 1984; Wiley et al., 1986). Wiley (1984) attributed the effects of potassium on cavitation to changes in membrane potential. Decreasing the concentration of extracellular potassium would hyperpolarize the cells of the embryo, whereas increasing extracellular potassium would depolarize the cells (Cohen et al., 1976; Wiley, 1984).

In the present study, only minor effects on in vitro development were observed by altering the potassium concentration in medium used to culture early pig embryos. When the potassium concentration was reduced to $1.5 \mathrm{mmol} \mathrm{l}^{-1}$ some devel- opmental retardation was apparent in embryos cultured at the one- and two-cell stage. Increasing the potassium concentration to $24 \mathrm{mmol} \mathrm{l}^{-1}$ reduced the number of cells, although overall development was unaffected. The differences in onset of hatching for four-cell embryos cultured in 3.0 versus 1.5 and $12.0 \mathrm{mmol}$ potassium $1^{-1}$ may merit further investigation as $3.0 \mathrm{mmol}$ potassium $\mathrm{l}^{-1}$ may be a more beneficial concentration for in vitro development. Evidence for improved development with reduced potassium was reported by Erbach $e t$ al. (1994) who demonstrated superior development of mouse embryos from outbred strains cultured in medium with $2.85 \mathrm{mmol}$ potassium $\mathrm{l}^{-1}$. It is of interest that the sodium: potassium ratio in the optimal medium described by Erbach et al. (1994) is 46, whereas the ratio in Whitten's medium containing $3.0 \mathrm{mmol}$ potassium $\mathrm{I}^{-1}$ in the present study is 40 . In a study investigating sodium tolerance by pig embryos, Beckman and Day (1993) concluded that the sodium concentration in modified Krebs' Ringer Bicarbonate medium (mKRB) used for embryo culture was detrimental compared with Whitten's medium (145 and $115 \mathrm{mmol} \mathrm{l}^{-1}$, respectively). In that study the sodium:potassium ratios were not manipulated and were reasonably close for mKRB and Whitten's medium (24.4 and 19.3, respectively). Similarly, Petters and Wells (1993) have described a medium containing $118.2 \mathrm{mmol}$ sodium $\mathrm{l}^{-1}$ and $5.4 \mathrm{mmol}$ potassium $\mathrm{l}^{-1}$ (sodium:potassium ratio $=22.0$ ) that supports the development of more than $90 \%$ of one- to four-cell embryos to the blastocyst stage. The effects of sodium seem related more to the absolute amount of sodium in the medium than to the sodium::potassium ratio. Biggers et al. (1993) increased the sodium concentration in culture medium from 85 to $125 \mathrm{mmol} \mathrm{l}^{-1}$ for mouse embryos, and observed poor development coupled with increases in intracellular sodium and decreases in intracellular potassium. However, the medium used in that study (Simplex Optimized Medium; SOM; Lawitts and Biggers, 1992), has a low potassium concentration $\left(0.6 \mathrm{mmol} \mathrm{l}^{-1}\right)$. Deleterious effects on embryo survival induced by intracellular ionic imbalances would be avoided if the balance of extracellular sodium and potassium, which results in little change to intracellular values, was determined. This may explain why optimal development was observed when the potassium concentration in SOM was increased to $2.85 \mathrm{mmol} \mathrm{l}^{-1}$ (referred to as KSOM) in the presence of $130.2 \mathrm{mmol}$ sodium $\mathrm{l}^{-\mathrm{I}}$ in the report by Erbach et al. (1994). Pig embryos developing in vitro appear to be tolerant of a wide range of potassium concentrations when the osmolality of the medium is maintained by adjusting the $\mathrm{NaCl}$ concentration. However, concentrations of 1.5 and $24.0 \mathrm{mmol} \mathrm{l}^{-1}$ may represent the limits of this tolerance.

Technical Paper No. 10,556, Oregon Agricultural Experiment Station.

\section{References}

Archibong AE, Petters RM and Johnson BH (1989) Development of porcine embryos from one-cell and two-cell stage to blastocysts in culture medium supplemented with porcine oviductal fluid Biology of Reproduction 41 1076-1083

Baker RD and Coggins EG (1968) Control of ovulation rate and fertilization in prepuberal gilts Journal of Animal Science 27 1607-1610 
Beckman LS and Day BN (1993) Effects of media $\mathrm{NaCl}$ concentration and osmolarity on the culture of early-stage porcine embryos and the viability of embryos cultured in a selected superior medium Theriogenology $39611-622$

Biggers JD, Whitten WK and Whittingham DG (1971) The culture of mouse embryos in vitro. In Methods in Mammalian Embryology pp 86-116 Ed. JC Daniel. WH Freeman and Co., San Francisco

Biggers JD, Lawitts JA and Lechene CP (1993) The protective action of betaine on the deleterious effects of $\mathrm{NaCl}$ on preimplantation mouse embryos in vitro. Molecular Reproduction and Development 34 380-390

Boldt J, Casas A, Whaley E, Creazzo T and Lewis JB (1991) Potassium dependence for sperm-egg fusion in mice Journal of Experimental Zoology 257 245-251

Borland RM, Biggers JD, Lechene CP and Taymor ML (1980) Elemental composition of fluid in the human Fallopian tube Journal of Reproduction and Fertility 58 479-482

Chatot CL, Ziomek CA, Bavister BD, Lewis JL and Torres I (1989) An improved culture medium supports development of random-bred 1-cell mouse embryos in vitro. Journal of Reproduction and Fertility 86 679-688

Cohen I, Daut J and Noble D (1976) An analysis of the actions of how concentrations of ouabain act on membrane currents in Purkinje fibres journal of Physiology 260 75-103

Erbach GT, Lawitts JA, Papaioannou VE and Biggers JD (1994) Differential growth of the mouse preimplantation embryo in chemically defined media Biology of Reproduction 50 1027-1033

Iritani A, Sato E and Nishikawa Y (1974) Secretion rates and chemical composition of oviduct and uterine fluids in sows Journal of Animal Science 39 582-588

Krisher RL, Petters RM, Johnson BH, Bavister BD and Archibong AE (1989) Development of porcine embryos from the one-cell stage to blastocyst in mouse oviducts maintained in organ culture Journal of Experimental Zoology 249 235-239

Lawitts JA and Biggers JD (1992) Joint effects of sodium chloride, glutamine and glucose in mouse preimplantation embryo culture media Molecular Reproduction and Development 31 189-194
McGaughey RW and Chang MC (1969) Meiosis of mouse eggs before and after sperm penetration Journal of Experimental Zoology 170 397-410

Petters RM and Wells KD (1993) Culture of pig embryos Journal of Reproduction and Fertility Supplement $\mathbf{4 8}$ 61-73

Pollard JW, Plante C and Leibo SP (1995) Comparison of development of pig zygotes and embryos in simple and complex culture media Journal of Reproduction and Fertility 103 331-337

Reed ML, Illera MJ and Petters RM (1992) In vitro culture of pig embryos Theriogenology 37 95-109

Roblero LS and Riffo MD (1986) High potassium concentration improves preimplantation development of mouse embryos in vifro. Fertility and Sterility 45 412-416

Roblero LS, Biggers JD and Lechene CP (1976) Electron probe microanalysis of the elemental microenvironment of oviductal cleavage stages of the mouse Journal of Reproduction and Fertility 46 431-434

Steel RGD and Torrie JH (1980) Enumeration data II: contingency tables. In Principles and Procedures of Statistics pp 495-520 Eds C Napier and JW Maisel. McGraw-Hill, New York

White KL, Hehnke K, Rickords LF, Southern LL, Thompson DL and Wood TC (1989) Early embryonic development in vitro by coculture with oviductal cells in pigs Biology of Reproduction 41 425-430

Whitten WK and Biggers JD (1968) Complete development in vitro of the preimplantation stages of the mouse in a simple chemically defined medium Journal of Reproduction and Fertility 17 399-401

Wiley LM (1984) Cavitation in the mouse preimplantation embryo: $\mathrm{Na} / \mathrm{K}$ ATPase and the origin of nascent blastocoel fluid Developmental Biology 105 330-342

Wiley LM, Yamani S and Muyden DV (1986) Effect of potassium concentration, type of protein supplement, and embryo density on mouse preimplantation development in vitro. Fertility and Sterility 45 111-119

Youngs CR, Ford SP, McGinnis LK and Anderson LH (1993) Investigations into the control of litter size in swine: I. Comparative studies on in vitro development of Meishan and Yorkshire preimplantation embryos Journal of Animal Science 71 1561-1565 